NBER WORKING PAPER SERIES

\title{
RACE AND OLDER AGE MORTALITY: EVIDENCE FROM UNION ARMY VETERANS
}

\author{
Dora L. Costa \\ Working Paper 10902 \\ http://www.nber.org/papers/w10902 \\ NATIONAL BUREAU OF ECONOMIC RESEARCH \\ 1050 Massachusetts Avenue \\ Cambridge, MA 02138 \\ November 2004
}

\begin{abstract}
I have benefited from the comments of participants at the 2004 NBER Cohort Studies meeting and the 2004 NBER Aging Summer Institute. I gratefully acknowledge the support of NIH grant R01 AG19637, NIH grant P01 AG10120, the Robert Wood Johnson Foundation, and the Center for Advanced Study in the Behavioral Sciences. This paper was written while the author was visiting the Center for Advanced Study in the Behavioral Sciences. The views expressed herein are those of the author(s) and not necessarily those of the National Bureau of Economic Research.
\end{abstract}

(C) 2004 by Dora L. Costa. All rights reserved. Short sections of text, not to exceed two paragraphs, may be quoted without explicit permission provided that full credit, including $\odot$ notice, is given to the source. 
Race and Older Age Mortality: Evidence from Union Army Veterans

Dora L. Costa

NBER Working Paper No. 10902

November 2004

JEL No. J15, N31

\begin{abstract}
$\underline{\text { ABSTRACT }}$
This paper uses the records of the Union Army to compare the older age mortality experience of the first black and white cohorts who reached middle and late ages in the twentieth century. Blacks faced a greater risk of death from all causes, especially in large cities, from infectious and parasitic diseases, from genito-urinary disease, and from heart disease, particularly valvular heart disease. Blacks' greater risk of death was the result both of the worse conditions in which they lived at the time of their deaths and of their lifelong poorer nutritional status and higher incidence of infectious disease. Compared to the 1821-40 black cohort, the 1841-50 black cohort was both under greater stress at a young age and had higher older age mortality rates.

Dora L. Costa

Department of Economics, E52-274C

MIT

50 Memorial Drive

Cambridge, MA 02142

and NBER

costa@mit.edu
\end{abstract}




\section{Introduction}

The first cohort of African-Americans to reach age 65 in the twentieth century faced tremendous stress throughout the life-cycle. In most of the North schools and public transport were segregated and employers were unwilling to hire for jobs other than common labor. Those blacks who crowded into the large cities, where infectious and parasitic diseases ravaged the worse sections of town, were described as the "poorest, the most thriftless, and perhaps the most troublesome part of the population" (quoted in McPherson 1965: 247). An index of their misery is provided by their experience during the 1832 cholera epidemic which in Philadelphia had a case rate twice as high among blacks as among whites (Ewbank 1987). In the South the work routine of pregnant women and the poor diet of slave children led to a mortality rate before age 5 of 385 per thousand and to mean heights that by age 10 had only reached the first percentile of modern height standards (Steckel 1986). In contrast, between 1880 and 1900 black mortality rates before age 5 were 265 per 1000 (Ewbank 1987) and slum children in today's developing countries attain the twelfth centile of modern height standards. Although the mortality rates and heights of adult slaves almost caught up to those of whites because slaves who reached field-hand age were fed a diet high in protein (Steckel 1986), the diet of African-Americans may have deteriorated under freedom as southern food production declined (Rose 1989; Ransom and Sutch 1977). Contemporary observers reported a high incidence of tuberculosis, pneumonia, typhoid, syphilis, malaria, pellagra, rickets, whooping cough, and hookworm among blacks in the postbellum era (Kiple and King 1981: 189: Holmes 1937: 39). The postwar migration of southern blacks to cities (Vickery 1977) probably compounded nutritional distress, because rural blacks may have lacked immunities to diseases common in urban areas and because only after 1900 did improved sanitation and water supplies lower black childhood mortality rates in cities.

This paper uses the records of the Union Army to compare the mortality experience of the first white and black cohorts who reached middle and older ages in the twentieth century. It quantifies 
the older age mortality penalty to being black and examines mortality differences between former slaves and freemen. It analyzes the importance of cities (and their clean-up) to the mortality differentials of the elderly, who are a particularly vulnerable group, and does so in a population that lived both in large cities and in rural areas and in both the north and the south. With few exceptions (e.g. Preston and Haines 1991), most studies of black and white mortality differentials have focused on larger cities or the northern states because smaller cities and rural areas and southern states often did not collect mortality statistics.

The Union Army data also allow me to examine mortality patterns for the different black and white cohorts born 1821-50. The 1830 s and even more so the 1840 s were a time of disease epidemics in both the north and the south (Kiple and King 1981: 147-157) and the decline in white health is well documented. Among the white population, heights began to decline with the cohorts born in the 1830s relative to earlier cohorts, reaching a trough in the 1880s (Fogel 1986). Genealogies show a decline in white life expectancy at age 20 in the first half of the nineteenth century (Pope 1992). The health evidence for the black population is mixed. Some data sources show a decline in heights similar to that observed among whites and other sources showing none (Margo and Steckel 1982; Komlos 1992; Komlos 1997; Bodenhorn 1999). Military records show a lower lung capacity and higher waist-hip ratio of later black relative to early black cohorts at military ages, suggesting that later cohorts may have had lower birth weights or a higher prevalence of early life infections (Costa 2004).

The implications of this paper extend beyond the Civil War cohort. The health of one generation can have a long reach. Lower health leads to lower productivity and output and therefore reduces investments in children's health and education. The death of the breadwinner could leave the family destitute. Because the Civil War cohort reached old age at the beginning of the twentieth century its experience can help us understand the early life conditions faced by more recent cohorts. These effects of early life conditions can persist to older ages, as seen in studies of the long-term effects 
of place of birth, disease exposure, and season of birth on older age mortality (Preston, Hill, and Drevenstedt 1998; Almond 2003; Doblhammer and Vaupel 2001; Costa and Lahey 2003).

\section{Older Age Mortality Trends}

Our knowledge of historic differentials in black and white mortality trends in the United States is based upon scattered and selective pieces of information. Until 1933 the United States did not have a complete death registration system and the states that did have a death registration system tended to be the northern states where relatively few blacks resided. I therefore establish trends in older age mortality rates by examining survivorship rates for ten year age groups of the native-born across the available micro census samples of the decennial censuses. That is, I calculate ten year mortality rates, $m_{i}$, for each cell $\mathrm{i}$, where a cell i consists of a race, age, sex, cohort, and region of birth group and estimate weighted OLS regressions, where the weights are equal to cell sizes. The estimating equations are

$$
\begin{aligned}
m_{i} & =\alpha+\beta B_{i}+\delta X_{i}+u_{i} \\
\log \left(m_{i}\right) & =\alpha+\beta B_{i}+\delta X_{i}+u_{i}
\end{aligned}
$$

where $B_{i}$ is a dummy variable indicating black race, $X_{i}$ is a vector of controls for age, sex, cohort, and region of birth and $u_{i}$ is an error term. Because a drawback of this method is mis-reporting of age, I do not include the very old in my analysis and restrict the age groups to 50-79.

Differential mortality rates by race at middle and late ages were at their highest at the beginning of the twentieth century (see Table 1). The better fitting linear specification shows that for the cohort born 1791-1810 and observed in 1870-80 there were no differential mortality effects by race. In contrast for the cohorts born 1821-1860 and observed in 1900-1920, black mortality rates were 25 percent higher than the mean. Within the $1821-1860$ cohorts, mortality rates rose 
for later black cohorts but not for later white cohorts (see Table 2). Black cohorts born after 1861 and observed beginning in 1940 started to catch up to their white counterparts in terms of mortality, with mortality rates roughly 11-12 percent above the mean. Although black mortality rates were 11-12 percent above the mean for both the cohorts born 1861-1900 and the cohorts born 1901-1940, mean mortality rates for both races were much lower for the 1901-1940 cohorts than for earlier cohorts. The absolute difference between white and black mortality rates declined. (The logarithmic specification magnifies the effects of differences at low mortality levels.) Racial mortality differentials were not statistically significantly different by region of birth. Data from the death registration states also show that there were substantial differentials in older age mortality rates at the beginning of the century and that these narrowed but are still sizable and persistent (see Figure 1). ${ }^{1}$

The large racial differentials observed for the 1821-60 cohort may be explained by both cohort and period effects. Increased urbanization, greater migration and immigration, and developments in transportation all facilitated the spread of disease and may explain why death rates rose over the middle of the nineteenth century, especially in urban areas. In the 1880s urban mortality was 50 percent higher than rural mortality and nowhere was the urban mortality penalty as large as in the poor areas of town where blacks lived. In Baltimore, Washington DC, Charleston, and New Orleans in 1880 half of all black children may have been dead by age 5. Then, between 1880 and 1900 white death rates started to fall whereas those for blacks they were constant or even rising. The biggest improvements in both black and white mortality rates occurred first in large urban areas and then in smaller ones. By 1940 the urban penalty had disappeared for whites though it still persisted for blacks (Haines forthcoming; Haines 2002; Preston and Haines 1991: 128-134; Ewbank 1987). Within cities the decline in black childhood mortality rates lagged behind that in

\footnotetext{
${ }^{1}$ The figure is likely to overstate black-white mortality differentials at older ages at the beginning of the twentieth century because during this time period the death registration states were mainly urban, northern states and the urban mortality penalty for blacks was large (Haines, forthcoming).
} 
white mortality rates because of delays in the black population receiving basic sewer and water services and because the lower relative income of blacks meant that a greater proportion of blacks lived in houses without adequate sanitation facilities (Troesken 2004; Ewbank 1987). Thus initial declines in white mortality rates should be accompanied by a widening of racial mortality differentials. Data for other age groups also suggest that racial mortality differentials were particularly high at the beginning of the twentieth century. Data from the death registration states (not shown) show large differentials in infant mortality rates at the start of the century which then narrowed but still persist to this day. Running regressions similar to Equation 1 for the same cohorts for ages 2049 shows that black-white mortality differentials were large in the 1870s, increased sharply in the early 1900s, and then narrowed again. ${ }^{2}$ These regressions, however, also imply that the elevated black mortality rates relative to those of whites observed for the cohorts born close to the end of slavery were not just an older-age phenomenon. They are observed at younger ages as well. The 1821-60 cohort may have been disadvantaged even before reaching middle and older ages.

\section{Econometric Framework}

Why were racial mortality differentials at middle and late ages so high for the cohort that reached these ages at the beginning of the twentieth century? The Union Army data can provide some clues. These longitudinal data have many advantages over aggregate mortality statistics. I can control for wartime experience, size of city of residence at both early and late ages, and socioeconomic and demographic characteristics. Misreporting of age cannot increase as the population ages. I can also examine causes of death and these provide some evidence on unobserved underlying morbidity.

I analyze the penalty to being black and to being black in an urban area by examining waiting

\footnotetext{
${ }^{2}$ The coefficients on the black dummy were $0.042(\hat{\sigma}=0.020)$ for the $1821-50$ cohort observed in $1870-80,0.108$ $(\hat{\sigma}=0.013)$ for the $1861-90$ cohort observed in 1910-20, and $0.034(\hat{\sigma}=0.011)$ for the 1901-1940 cohort observed in 1940-1990.
} 
time until death using hazard models, in which the estimated hazard $\lambda(t)$ is

$$
\lambda(t)=\exp \left(B^{\prime} \beta_{B}+C^{\prime} \beta_{C}+\left(B^{\prime} \times C^{\prime}\right) \beta_{B C}+X^{\prime} \beta_{X}\right) \lambda_{0}(t)
$$

where $\mathrm{B}$ is a vector indicating that the individual is black, $\mathrm{C}$ is vector of control variables indicating city size, $B \times C$ is the interaction between black and city size, $\mathrm{X}$ is a vector of control variables for wartime experience, socioeconomic status, and demographic characteristics, and $\lambda_{0}(t)$ is the baseline hazard which I assume to Gompertz, $\lambda_{0}(t)=\exp (\gamma t)$. I examine both cities at enlistment and city of residence circa 1900. I define a large city at enlistment as one whose population was 50,000 or more in 1860 (the top 13 cities). In previous work I found that among white veterans those who enlisted in one of these cities had higher older age mortality even controlling for later residence, but that there were no older age mortality effects to enlisting in smaller cities (Costa 2003). I define a large city of residence in 1900 as one of the top 100 cities in the United States (a population of 38,307 or more). Because the sample of black veterans is not yet linked to the 1900 census, place of residence information is often not precise, but the top 100 cities are easily identified. This classification will most likely underestimate the urban penalty. Relative to cities with populations below 5,000 and to rural areas, cities with populations of 5,000 to 25,000 had higher mortality rates in 1900 (Haines forthcoming).

I test for cohort effects by looking within the black sample and using hazard models of the form

$$
\lambda(t)=\exp \left(Y^{\prime} \beta_{Y}+X^{\prime} \beta_{X}\right) \lambda_{0}(t)
$$

where $\mathrm{Y}$ is a vector indicating birth cohort, $\mathrm{X}$ is vector of control variables, and $\lambda_{0}(t)$ is the baseline hazard which I assume to Gompertz, $\lambda_{0}(t)=\exp (\gamma t)$. The hazard ratios that I report indicate whether a one unit change in an independent variable gives an increase or decrease in the odds of an event. 
For men for whom cause of death is known, I also estimate independent competing risk models for specific causes of death, treating other causes of death as censored. These provide some clues on why mortality experience differed by city size or by cohort of birth. The primary causes of death studied are the combined categories of 1) heart and cerebrovascular disease; 2) infectious and parasitic disease and bronchitis, pneumonia, and influenza; and, 3) genito-urinary disease (including all mention of the prostate and of kidney problems). I can further subdivide heart and cerebrovascular into its two separate components. Although heart disease is often not classified by type, in some cases I can identify valvular and ischemic heart diseases to investigate the etiology of heart disease. ${ }^{3}$ Although the three categories were picked because of their importance in the Union Army data, they were also important causes of death for the population as a whole. DuBois (1899: 159) wrote that in Philadelphia in 1884-90, "The Negroes exceed the white death rate largely in consumption, pneumonia, diseases of the urinary system, heart disease and dropsy, and in stillbirths; they exceed moderately in diarrheal diseases, diseases of the nervous system, malarial and typhoid fevers."

High infectious disease rates among African-Americans could increase their mortality rates from all three causes of death, particularly in large cities. Although black rejection rates for Civil War service for pulmonary tuberculosis were lower than those of whites, the case rate for tuberculosis was 6.06 per 1000 for white soldiers and 7.26 per 1000 for black soldiers. The tuberculosis death rate was 2.18 per 1000 for whites and 6.31 for blacks. Death rates per thousand for respiratory disease were 7.40 for whites and 32.35 for blacks (cited in Holmes 1937: 75). The army experience suggests that migration, particularly to large cities, may have led to a tuberculosis and respiratory disease epidemic among the black population. However, some of the initial preconditions may already have been present. Rejection rates for scrofula (a degeneration of the lymphatic glands due to tuberculosis) were higher for blacks than for whites (Holmes 1937: 75). Kiple and

\footnotetext{
${ }^{3}$ Valvular heart disease is defined as all deaths which mention valvular heart disease or rheumatism. Ischemic heart disease is defined as all mentions of atherosclerosis, coronary heart disease, heart failure, or myocardial insufficiency.
} 
King (1981: 142) point out in that in the first and second generation exposed to tuberculosis, there is extensive glandular involvement and that only in the third exposed generation is classic pulmonary tuberculosis observed. Whooping cough in infancy predicts later pulmonary distress and in Charleston, SC between 1822 and 1848 the average annual death rate for blacks from whooping cough was 650.5 per 1000 compared to 305.8 per thousand for the white population (cited in Holmes 1937: 64). World War I statistics, which show that the rate of admission to sick report for pulmonary tuberculosis was two and a half times as high among black soldiers as among white soldiers (Holmes 1937: 81) suggest that the pulmonary epidemic was long-lasting.

Infectious disease also has chronic sequelae. A substantial fraction of heart disease in the past was valvular and therefore due to rheumatic fever, a disease associated with crowding. Other forms of heart disease may have resulted from infectious disease as well. Infections that have cardiac involvement include syphilis, measles, and typhoid fever. Syphilis can also lead to stroke. The experience of the Metropolitan Life Insurance Company from 1911 to 1930 led one researcher to conclude that syphilis accounted for a third of all cardiac conditions among blacks and that it could explain both premature deaths from cerebral hemorrhage and arteriosclerosis (cited in Holmes 1937: 113). The category of genito-urinary disease may also include deaths due to tertiary syphilis. Neurosyphilis can have urological manifestations; glomerulonephritis (a type of kidney disease) is a sequelae of tertiary syphilis; and, syphilis may increase the risk of prostate cancer (Hayes et al. 2000; Ertruk, Sheinfeld, and Davis 1989). Syphilis rates were higher among the black population than the white population and racial differences were probably bigger in larger cities because black men in metropolitan areas were more likely to live apart from their families than men in non-metropolitan areas. ${ }^{4}$ During World War I, 12.63 per 1000 of white soldiers were

\footnotetext{
${ }^{4} \mathrm{~A}$ higher prevalence rate of syphilis and other sexually transmitted diseases in large cities is consistent with the high rates of childlessness observed among ever married black women. In 1910 among ever married black women age 40-49 living in metropolitan areas 18 percent were childless compared to 8 percent of those living in non-metropolitan areas. The comparable figures for white women of the same age were 12 and 9 percent, respectively (estimated from the integrated public use micro census samples).
} 
diagnosed with syphilis compared to 64.99 per thousand of black soldiers (cited in Holmes 1937: 69).

\section{Data}

By the end of the Civil War, 186,017 black men had entered the US Colored Troops, 26 percent of them from the free states, 22 percent of them from the border states and the District of Columbia, and 50 percent of them from Confederacy. Three-quarters of all Colored Troops were former slaves. The fraction of age-eligible black men who served was 78 percent in the free northern states, 34 percent in the border states, and 11 percent in the Confederacy (Metzer 1981). In the Confederacy there were active recruitment efforts whenever an area was liberated by the Union Army and the states that were occupied before the end of the war provided the most men. ${ }^{5}$ In the random sample of black soldiers used in this paper, 91 percent were volunteers (a fraction similar to that for whites), 7 percent were substitutes, and 2 percent were draftees.

The black sample used in this paper is based upon the military service and pension records of 5,673 black Union Army soldiers in 51 infantry companies. ${ }^{6}$ All of the men in the 51 companies were sampled. The military service records provide information on events such as wartime deaths, injury and illness, antebellum occupation, age at enlistment, and place of enlistment. Place of enlistment is not as good a proxy for place of residence for southern enlistees as it is for northern enlistees because there were fewer recruiting centers in the south and these would draw from the neighboring countryside for enlistees. The pension records document postbellum mortality,

\footnotetext{
${ }^{5}$ It was not just slaves who were mistreated who joined the Union Army. Among the first 10 slave narratives that recounted own or a family member's voluntary service in the Union Army (out of the first 12 narratives there are two recounting capture in the Union Army while a servant in the Confederate Army), 6 mentioned that the master was good, 3 did not mention the master, and 1 recounted escape to the Union Army after severe mistreatment. See the database, American Slavery: A Composite Autobiography.

${ }^{6}$ The sample represents roughly 2.7 percent of all blacks serving. The data were collected by a team of researchers led by Robert Fogel. Once the data are completed and cleaned, they will be available from the Center for Population Economics at the University of Chicago, http://www.cpe.uchicago.edu.
} 
residence, occupation, and writing ability. The control variables that I create are dummies indicating occupation at enlistment (farmer, artisan, laborer, professional or proprietor, and unknown), dummies indicating occupation circa 1900 (farmer, artisan, laborer, professional or proprietor, and unknown), a dummy indicating whether or not the veteran could write, dummies indicating region of residence circa 1900 (east, midwest or west, border, and south), dummies indicating whether the soldier ever was a POW and whether the soldier ever had specific medical conditions while in the army (tuberculosis, stomach, rheumatic fever, respiratory, diarrhea, typhoid, malaria, fever, and wounded), size of city of enlistment or residence in 1900, and age or cohort dummies.

The black sample is representative of the US Colored Troops in terms of geography and slave status. Twenty-nine percent of the men in the sample were free, 28 percent of them were from the free states, and the remaining 72 percent were from the border and southern states. Twentytwo percent of these men died while in the service, a higher service mortality rate than that of 14 percent for white soldiers, mainly because sanitary conditions for black troops were so poor.

Comparisons are drawn with a random sample of white Union Army soldiers, which is based upon the military service of almost 35,000 men and is described extensively elsewhere (e.g. Costa 2000; Costa 2002; Costa 2003). ${ }^{7}$ The white sample is representative of the northern-born and pre-1861 immigrant population in terms of wealth (Fogel 2001). Although the white sample is primarily a northern sample whereas the black sample is primarily a southern sample, recall that the census data revealed no statistically significant difference in racial differentials by region of birth.

Two different subsets of the Union Army samples are used. Both restrict the data to men on the pension rolls because the pension rolls are the only source of information on subsequent mortality. One subset consists of everyone alive and on the pension rolls at age 60 and is used to examine cohort effects. This subset provides data on 10,872 white native-born men and 894 black native-

\footnotetext{
${ }^{7}$ The white Union Army sample is available at http://www.cpe.uchicago.edu.
} 
born men. The second subset is of everyone alive and on the pension rolls in 1900 and allows me to control for socioeconomic status and provides better controls for residence circa 1900. This subset provides data on 9605 native-born white veterans and 954 native-born black veterans.

Entry on the pension rolls used to obtain information about subsequent mortality was relatively non-discriminatory by the standards of the time. Both black and white veterans were eligible for a pension for war-related injuries. In 1890 pensions began to be paid for any disability, regardless of its relation to the war, and the Pension Bureau began to consider age 65 or older as a disability unless men were "unusually vigorous." By 1907 old age was officially recognized by Congress as a disability. Among all men who identified themselves as Union veterans in the 1910 census, 86 percent of the white veterans and 79 percent of the black veterans were found in the pension records. Soldiers who survived the war were less likely to have a pension if they were deserters (deserters who never returned to fight were ineligible), if they had never been injured in the war, if they had never been promoted, if they were from a regiment that saw little fighting, if they had been born in the Confederacy, if they were free men at enlistment, and if they were dark-skinned.

The veteran samples contain men who circa 1900 were more northern, of slightly higher occupational status, and more urban than the postbellum black population of the same age. Twenty-two percent of black veterans in the sample lived in one of the top 100 cities in the United States circa 1900. Among non-veterans of the same age group in 1910 the comparable figure was 10 percent. Veterans had higher urbanization rates than non-veterans in the south as well. Among black veterans who were on the pension rolls by 1900, 41 percent of those reporting a last occupation were farmers and 11 percent were professionals, proprietors, or artisans. The comparable figures for all blacks in the same age group reporting an occupation in 1900 were 49 and 8 percent, respectively. ${ }^{8}$

\footnotetext{
${ }^{8}$ Figures for non-veterans and for all blacks are calculated from the 1900 and 1910 Integrated Public Use Census Sample.
} 


\section{Mortality of Black and White Veterans}

The survival probabilities of both black and white native-born Union Army veterans were substantially lower than those of men of the same race observed in the first National Health and Nutrition Examination Survey and followed until 1992 (see Figure 2) and the largest mortality improvement has been for blacks. Even though black men first observed in the 1970s achieved roughly the survival probabilities of white Union Army soldiers, the survival probabilities of black Union Army veterans were very low relative relative to those of white veterans. Adjusting for age differences, after 20 years over 60 percent of native-born white veterans age 50-74 in 1900 were still alive compared to roughly 40 percent of black veterans in the same age group (see Figure 2). When black veterans are compared with white veterans born abroad, they most closely resemble the Irish (see Figure 3).

Figure 2 probably underestimates mortality improvements for both races for the population as a whole and particularly so for blacks. Both black and white native-born Union Army veterans had lower 10 year mortality rates at middle and older ages than their racial counterparts in the population as a whole. Examining 10 year survivorship rates in the Integrated Public Use Census data implies that the 10 year mortality rates for black men age 50-59 and 60-69 were 0.386 and 0.559, respectively. The respective mortality rates for black Union Army veterans were 0.346 and 0.431. Among white men in the census 10 year mortality rates at ages 50-59 and 60-69 were 0.232 and 0.412 , higher than the rates of 0.215 and 0.347 in those age groups observed among white Union Army veterans.

Cause of death information provides some clues on the likely causes of the large racial mortality differentials observed among Union Army veterans. This information is available for 44 percent of black veterans and 48 percent of white veterans. It is more likely to be available if there was a surviving spouse and is more common for later cohorts. Availability in the black sample does not depend upon region of residence, but it does depend upon urbanization in 1900. Thus cause 
of death is not known for 62 percent of black men who in 1900 lived in a city that was not one of the 100 largest cities in the country. For black men who lived in one of the 100 largest cities the comparable figure is 38 percent. Among black men with some cause of death information, 20 percent of those in the south had a vague or unclassifiable cause of death whereas only 10 percent of those in the north did. Among both whites and blacks vague and unclassifiable causes of death were also more common when there was no surviving spouse and are more common for earlier cohorts.

Table 3 shows that the proportion of deaths attributable to heart and cerebrovascular disease rises for later white cohorts but remains constant across black cohorts. ${ }^{9}$ The proportion attributable to infectious and parasitic diseases and to bronchitis, pneumonia, and influenza falls for later white cohorts but remains constant across black cohorts. The proportion attributable to genito-urinary disease rises for later cohorts of either race.

\section{Death and the City}

Large cities were deadly for both whites and blacks, but especially so for blacks. Figure 4 shows that among men who enlisted in cities of 50,000 or more in 1860 there was a substantial urban mortality penalty at late ages for white veterans. The magnitude of the urban penalty for whites was equivalent to that of being a black slave. Although sample sizes are small, free blacks who enlisted in cities with a population of 50,000 or more suffered a tremendous older age mortality penalty. In contrast, there was no such urban penalty for black slaves. Perhaps place of enlistment was not as good an indicator of place of residence or birth for slaves as it was for free men. Whites who in 1900 lived in one of the 100 largest cities fared no worse than whites who lived in smaller

\footnotetext{
${ }^{9}$ Note that cerebrovascular death rates are lower for blacks than for whites. The 1915 data for the death registration states show that at ages $65+$ deaths from cerebrovascular disease were lower for whites than for non-whites. By 1925 , non-white cerebrovascular death rates were lower only at ages 75+ and by 1980 they were lower only at ages 85 (see the Center for Disease Control's series hist290, http://www.cdc.gov/nchs/datawh/statab/unpubd/mortabs/hist290.htm.
} 
cities (see Figure 5). In contrast, among blacks there was an urban mortality penalty by size of city of residence in 1900.

The urban mortality penalties observed in Figures 4 and 5 persist controlling for wartime experience, socioeconomic status, and later and earlier residence. Table 4 shows that there was a permanent scarring effect of enlisting in a large city for whites (their odds of dying were 1.2 times greater than those of whites enlisting in a small city) whereas for blacks there was none. (Blacks enlisting in large cities had lower mortality rates than those enlisting in smaller cities, largely because this category is dominated by former slaves who enlisted in large southern cities but may not have lived there.) The odds of death were 1.3 times higher for black veterans who in 1900 lived in a large city than for black veterans who did not live in a large city whereas for whites there was no effect on mortality of living in a large city in 1900. Odds of death and city size were not linearly related (not shown). There was no urban penalty for either whites or blacks of living in one of the top 13 cities in the country in 1900, perhaps because the largest cities were the first ones to install a modern sewage and water infrastructure (and suggesting also that persistence of residence does not explain the effect of city of enlistment on older age mortality). For whites there was no urban penalty to living in the next 87 largest cities (the hazard ratio was $1.014, \hat{\sigma}=0.049$ ), but for blacks there was a substantial penalty (the hazard ratio was $1.328, \hat{\sigma}=0.144$ ).

A high urban mortality penalty for the top 100 cities explains roughly 15 percent of racial differences in older age mortality rates. The difference in the predicted number of years lived between blacks and whites in the sample was 2.0 years. Had there been no men in large cities in 1900 this difference would have fallen to 1.7 years. Even in a sample where blacks were more urban than the black population as a whole, relatively few men lived in large cities and, as Table 4 shows, even in smaller cities the penalty to being black was substantial. The odds of death for a black veteran in a small city and age 50-74 in 1900 were 1.3 times those of a native-born white veteran in the same age group and in a small city controlling for individual socioeconomic and 
demographic characteristics at enlistment, while in the service, and circa 1900.

The penalty to being black was large in all regions of the country, but especially large in the border states (not shown). When the white and black samples were restricted to men living within a particular region, the hazard ratio on the black dummy variable was $1.538(\hat{\sigma}=0.153)$ for men living in the border states, $1.366(\hat{\sigma}=0.144)$ for men living in the south, and $1.190(\hat{\sigma}=0.087)$ for men living in the former free states. The racial mortality differential between the border states and the former free states was statistically significantly different at the 10 percent level.

Hazard regressions that examine the effects of slave status reveal the same patterns seen in Figure 4 (not shown). Controlling for wartime experience, socioeconomic status, and later and earlier residence, both ex-slaves and freemen fared worse than whites. Although the hazard ratio on the interaction term between the dummy for a free black man and the dummy for enlisting in a large city was not statistically significantly different from 1 , suggesting that there was no additional urban penalty for free blacks relative to native-born whites, the magnitude suggests that free blacks did face an additional urban penalty. Both free blacks and the ex-slaves faced similarly sized urban penalties to living in one of the top 100 cities in 1900 relative to whites.

Table 5 illustrates the importance of infectious disease in explaining racial mortality differentials. Elevated black mortality rates both in large cities and in smaller cities and rural areas are due to infectious and parasitic disease and to bronchitis, influenza, and pneumonia. The odds of a black veteran during from infectious disease were 1.5 times higher than those of a white veteran. Although the magnitude of the coefficient on the interaction between the black dummy and top 100 city suggests that mortality rates from these causes were higher for blacks in large than in small cities, the results are not statistically significant. Blacks living in a large city in 1900 faced an odds of dying of genito-urinary disease that was twice that of blacks living in a smaller city or of whites and an odds of dying from cerebrovascular and heart disease that was 1.5 times that of blacks living in a smaller city or of whites. Excess black deaths in cities from the combined cate- 
gory of cerebrovascular and heart disease were mainly due to cerebrovascular disease. In smaller cities and rural areas blacks were at lower risk of death from cerebrovascular disease than whites (the hazard ratio on the black dummy was 0.428 with a standard error of 0.146 and the hazard ratio on the coefficient of the interaction between black and the top 100 cities was 3.327 with a hazard ratio of 1.354). Recall that because black men in metropolitan areas were more likely to live apart from their families than black men in non-metropolitan areas, syphilis and other sexually transmitted diseases may have been more prevalent in large cities, leading to higher death rates from genito-urinary disease and from cerebrovascular disease. Blacks in both urban and rural areas suffered from a higher death rate from valvular heart disease (the hazard ratio on the black dummy was 2.770 , with a standard error of 0.662 ), but there was no urban penalty for valvular heart disease. There is some suggestion of an urban penalty to ischemic disease, but the results are not statistically significant.

Certain wartime diseases predicted older age mortality by cause. Respiratory infections during the war were associated with later mortality from infectious and parasitic disease and bronchitis, influenza, and pneumonia. Wartime rheumatic fever predicted later heart disease mortality. Among blacks (but not whites), wartime syphilis predicted death from genito-urinary diseases and from cerebrovascular disease. Higher unobserved lifetime incidences of respiratory infections, rheumatic fever, or syphilis and other sexually transmitted disease, among blacks are therefore consistent with their higher death rates from infectious and respiratory disease, heart conditions, and genito-urinary disease.

Differences in socioeconomic status, as proxied by occupation circa enlistment and 1900, could not explain racial mortality differentials. Among whites, men who were laborers circa 1900 had higher mortality rates than men who were professionals and proprietors or farmers. Among blacks only men who were servants circa 1900 had a mortality advantage. 


\section{The Unfortunate Cohort}

Within the Union Army data, as in the national census data, racial mortality differences at older ages were much smaller for earlier than for later cohorts but widen as black mortality rates increased (see Figure 6). Among men first observed at age 60 black life expectancy was lower for the cohort born in 1831-40 relative to the 1821-30 cohort and even lower for the cohort born in 1841-50. Hazard models that control for wartime service experience and socioeconomic and demographic characteristics at enlistment (not shown) indicate that the odds of death rose for later black cohorts and fell for later white cohorts. Although black veterans born in 1821-30 had lower mortality rates than white veterans, later cohorts had higher mortality rates. The odds that a white veteran born 1841-52 would die relative to a white veteran born $1821-30$ were $0.887(\hat{\sigma}=0.031)$. The odds that a black veteran born 1841-52 would die relative to a white veteran born 1821-30 were $2.106(\hat{\sigma}=0.388)$.

Competing risk hazard models show that relative to white cohorts and to black cohorts born before 1841, black cohorts born 1841-52 were at greater risk of death from genito-urinary disease and from infectious and parasitic disease, from bronchitis, influenza, and pneumonia (see Table 6). The odds of death from genito-urinary disease for a black veteran born 1841-52 were 1.7 times higher than those of a black veteran born before 1841 or those of a white veteran. The odds of death from infectious and parasitic disease for a black veteran born 1841-52 were 1.8 times higher than those of a black veteran born before 1841. In contrast, white cohorts born 1841-52 faced a risk of death from infectious and parasitic disease that was 0.7 times lower than that faced by earlier white cohorts.

Infectious disease played a large role in the black-white mortality gap. Using the competing risk specification, I estimate that eliminating infectious disease deaths would have reduced the predicted racial differential in the average number of years lived past age 60 from 0.9 to 0.4 years, a 56 percent decrease in the racial differential. This fraction underestimates the true effects of 
eliminating infectious disease because it does not account for the impact of eliminating infectious disease on deaths from chronic disease.

Relative to earlier black cohorts later black cohorts also faced higher death rates from cerebrovascular and heart disease. Although the hazard ratio is not statistically significantly different from 1, its magnitude implies that the odds of death from cerebrovascular and heart disease were 1.3 times higher for the black cohorts born 1841-52 than for the black cohorts born earlier. In contrast, white cohorts born 1841-52 faced a risk of death from cerebrovascular and heart disease that was 1.1 times higher than those of earlier white cohorts. Excess deaths among the later black cohorts relative to the earlier black cohorts are due not to cerebrovascular disease, but to heart disease, especially valvular heart disease. When the sample was restricted to blacks only, the odds of death from valvular heart disease for the cohort born 1841-52 were 2.147 times as high as those for the cohorts born before 1841. Unlike blacks, later white cohorts faced lower risk of death from valvular heart disease and a higher risk of death from cerebrovascular and ischemic heart disease compared to earlier white cohorts. The hazard ratios on the 1841-52 cohort dummy in the competing risk regressions on death from cerebrovascular, valvular, and ischemic heart disease were $1.153(\hat{\sigma}=0.099), 0.803(\hat{\sigma}=0.093)$, and $1.226(\hat{\sigma}=0.126)$, respectively.

The higher mortality of late relative to early black cohorts was not just an urban phenomenon. Table 7 shows that within the black sample the cohort born 1841-52 had higher all cause mortality than the cohorts born before 1841, but that there was not a differential effect by city size. Deaths from genito-urinary and cerebrovascular and heart disease were higher for the 1841-52 black cohort than for earlier black cohorts and there was no differential effect by city size. However, the excess infectious and parasitic disease mortality of the 1841-52 black cohort relative to earlier cohorts was predominately an urban phenomenon. Although the hazard ratio on the interaction term between city size in 1900 and cohort was statistically insignificant, its magnitude implies that a black veteran who was born in 1841-52 and who lived in a large city in 1900 faced an odds of dying from 
infectious and parasitic disease that was 2.5 times greater than that of a black veteran born in the same years who did not live in a large city in 1900. The 1841-52 cohort may have been exposed to worse conditions within cities. It may also have had less resistance to disease at late ages because of poor environmental conditions, including heavy disease exposure, at younger ages.

Why was older age mortality so high for later black cohorts compared to earlier cohorts? Kiple and King (1981: 127-129; 147-157) document cholera epidemics in the United States in the 1840s, including in the south, and what may have been pellagra epidemics in the south in the 1840s. The 1840s were poor agricultural years, following disastrous agricultural years, and nutritional intake may have been reduced (Kiple and King 1981: 127). Height data suggest that later cohorts of both white and black soldiers faced greater stress than earlier cohorts. Among white Union Army soldiers mean heights of men age 23-49 declined by $1.5 \mathrm{~cm}$ between the 1821-30 cohort and the 1841-50 cohort. Among black Union Army soldiers the mean decline across cohorts was $2.1 \mathrm{~cm}$ and declines are observed in all regions of the country. ${ }^{10}$ However, controlling for height in the regressions had no effect on estimated cohort effects and height was not a significant predictor of older age mortality. Among Union Army soldiers measured by the Sanitary Commission, AfricanAmericans had lower vital capacity (a measure of lung capacity associated with mortality from respiratory disease and stroke) at all ages, but the difference was more pronounced at younger ages. At younger ages African-Americans also had a higher waist-hip ratio (a predictor of stroke and ischemic heart disease) whereas at older ages their waist-hip ratios were the same as those of older white soldiers (Costa 2004). Thus the precursors of later susceptibility to respiratory infections and to heart disease may already have been present among later black cohorts prior to the Civil War. If nutritional and disease conditions deteriorated after the end of the Civil War, the

\footnotetext{
${ }^{10}$ The height declines observed in the Union Army data contrast with the findings of Richard Steckel, who finds that among young slaves listed in all of the available slave "manifests" (shipping documents used in inter-regional trade) there was no decline in height (personal communication), a result consistent with that of Margo and Steckel (1982) using a smaller sample of manifests. Komlos (1992) finds a decline in heights for later cohorts of free blacks in Maryland similar to that observed among Union Army soldiers, but among Georgia convicts he he finds a decline in the 1850s and 1880s (Komlos 1997). Bodenhorn (1999) finds a height decline for free Virginia blacks.
} 
weaker, later cohorts would have been the most affected and, because the young are more likely to migrate, later cohorts were more likely to be exposed to new diseases and the physical stress of a move.

\section{Conclusion}

In the United States, African-Americans experienced a later epidemiological transition than whites. The start of the sustained decline in black child mortality rates lagged the decline in white infant mortality rates by 20 to 30 years (Haines 2002). At older ages, black Union Army veterans faced higher death rates than white veterans and were more likely than white veterans to die of infectious and parasitic disease. Had it been possible to eliminate deaths from infectious disease, the racial mortality differential in years lived at older ages would have fallen by 56 percent. This is probably an underestimate of the effect of eliminating infectious disease. Blacks' death rates from genitourinary disease possibly resulted from syphilis and their higher death rates from heart disease possibly resulted from rheumatic fever. Their odds of dying from such degenerative diseases as stroke or ischemic heart were lower than those of whites. In large cities, where racial mortality differentials were bigger than in smaller cities and where the epidemiological transition first began, black veterans faced a higher death rate than white veterans both from infectious and parasitic disease and from degenerative disease, partly because some degenerative diseases were caused by infections such as syphilis. The urban mortality penalty faced by blacks accounted for roughly 15

percent of the mortality differential between blacks and whites. Blacks' greater risk of death from infectious and parasitic disease was the result both of the worse conditions in which they lived at the time of their deaths and of their poorer nutritional status and higher incidence of infectious disease throughout their lives. Compared to the 1821-40 black cohorts, the 1841-50 black cohort both was under greater stress at a young age and had higher older age mortality rates, from all 
causes, from infectious and parasitic disease, from genito-urinary disease, and from heart disease, especially valvular heart disease. Although the 1841-50 white cohort suffered more stress in its growing years than the 1821-40 white cohort, older age mortality rates were the same across the different white cohorts.

Racial older age mortality differentials fell during the twentieth century as infectious and parasitic disease rates among African-Americans fell. Why did these disease rates fall? The competing explanations, while related, can be loosely grouped as ecobiological (e.g. a natural decline in the virulence of a pathogen), public health, and socioeconomic. While scarlet fever represents one of the few cases where a decline in virulence may have occurred, it is an important case because scarlet fever often precedes rheumatic fever and decreases may help explain reductions in valvular heart disease deaths at older ages. However, the decline in virulence was not necessarily "natural" - the adoption of effective isolation practices between 1900 and the 1930s may have eliminated the severer strains (Chapin 1926). The substantial effects of such public health investments as sanitation and water filtration on mortality rates and such public health campaigns as those against hookworm on child schooling outcomes have been well-documented (Troesken 2004; Condran and Cheney 1982; Bleakley 2002). Cities also invested in disease reporting and quarantining systems, and in conjunction with private philanthropists, in well-baby and -child care (including vaccination) and in campaigns against specific diseases such as syphilis. Foods were fortified with iron. Because blacks and the poor could ill afford self-protection measures or treatment, they were the biggest beneficiaries of these campaigns (Troesken 2004; Bleakley 2002; Costa and Kahn 2003). However, public health interventions cannot fully explain the decline in disease rates. Death rates from typhoid were falling in many cities even before public health interventions as knowledge of the germ theory of disease spread and people adjusted their behavior accordingly (Troesken 2004: 137-78). Declining death rates from tuberculosis prior to any changes in medical technology or in public health reforms led McKeown (1976) to argue that improved nutrition had to be 
a factor. Higher incomes can purchase more and better food, less crowding in which air-borne diseases spread, and less work away from home for the mother. Woodbury's (1926: 139) data on infant mortality rates in large cities at the beginning of the twentieth century suggested that a large fraction of the difference in black and white infant mortality rates was accounted for by blacks' lower incomes. The estimated narrowing of the black-white wage gap between 1890 and 1940 (Smith 1986) may therefore have played a role in reducing racial older age mortality differentials. The lagged improvement in black relative to white wages and in black relative to white infectious disease rates may explain why older age mortality differentials by race still persist.

\section{References}

[1] Almond, Douglas V. 2003. "Is the 1918 Influenza Pandemic Over? Long-term Effects of In Utero Influenza Exposure in the Post-1940 U.S. Population.” Unpublished Manuscript. Columbia University.

[2] Bleakley, Hoyt. 2002. "Disease and Development: Evidence from Hookworm Eradication in the American South.” Unpublished manuscript. University of California, San Diego.

[3] Bodenhorn, Howard. 1999. "A Troublesome Caste: Height and Nutrition of Antebellum Virginia’s Rural Free Blacks.” Journal of Economic History. 59(4): 972-96.

[4] Chapin, Charles V. 1926. "Changes in type of contagious disease, with special reference to smallpox and scarlet fever." Journal of Preventive Medicine. 1(September): 1-29.

[5] Costa, Dora L. 2000. "Understanding the Twentieth Century Decline in Chronic Conditions Among Older Men.” Demography. 37(1): 53-72.

[6] Costa, Dora L. 2002. "Changing Chronic Disease Rates and Long-term Declines in Functional Limitation Among Older Men.” Demography. 39(1): 119-38.

[7] Costa, Dora L. 2003. Understanding Mid-life and Older Age Mortality Declines: Evidence from Union Army Veterans." Journal of Econometrics. 112(1): 175-92.

[8] Costa, Dora L. 2004. "The Measure of Man and Older Age Mortality: Evidence from the Gould Sample." Journal of Economic History. 64(1): 1-23. 
[9] Costa, Dora L. and Matthew E. Kahn. 2004. "Public Health and Mortality: What Can We Learn from the Past?" Unpublished manuscript. MIT.

[10] Costa, Dora L. and Joanna Lahey. 2003. "Becoming Oldest-Old: Evidence from Historical U.S. Data.” National Bureau of Economic Research Working Paper No. 9933.

[11] Doblhammer, Gabriele and James W. Vaupel. 2001. "Lifespan depends on month of birth." Proceedings of the National Academy of Sciences. 98(5): 2934-9.

[12] DuBois, W.E. Burghardt. 1899. The Philadelphia Negro: A Social Study. Philadelphia: University of Pennsylvania.

[13] Ertruk, E, J Sheinfeld, and RS Davis. 1987. "Voiding dysfunction with tertiary syphilis." Urology. 30(3): 284-6.

[14] Ewbank, Douglas C. 1987. "History of Black Mortality and Health Before 1940." The Milbank Quarterly. 65(Suppl. 1): 100-28.

[15] Fogel, Robert W. 1986. "Nutrition and the Decline in Mortality since 1700: Some Preliminary Findings." In Stanley L. Engerman and Robert E. Gallman, Eds., Long-term Factors in American Economic Growth. Chicago: University of Chicago Press.

[16] Kiple, Kenneth F. and Virginia Himmelsteib King. 1981. Another Dimension to the Black Diaspora: Diet, Disease, and Racism. Cambridge-New York: Cambridge University Press.

[17] Komlos, John. 1992. "Toward an Anthropometric History of African-Americans: The Case of the Free Blacks in Antebellum Maryland." In Claudia Goldin and Hugh Rockoff, Eds., Strategic Factors in Nineteenth Century American Economic History. Chicago: University of Chicago Press: 297-329.

[18] Komlos, John. 1997. "On the Puzzling Cycle in the Biological Standard of Living: The Case of Antebellum Georgia.” Explorations in Economic History. 34(4): 433-59.

[19] Haines, Michael R. 2002. "Ethnic Differences in Demographic Behavior in the United States: Has There Been Convergence?” NBER Working Paper No. 9042, July.

[20] Haines, Michael R. Forthcoming. "The Urban Mortality Transition in the United States, 1800 to 1940." Annales de Demographie Historique.

[21] Hayes, RB, LM Pottern, H Strickler, C Rabkin, V Pope, GM Swanson, RS Greenberg, JB Schoenberg, J Liff, AG Shwartz, RN Hoover, JF Fraumeni Jr. 2000. "Sexual behavior, STDs and risks for prostate cancer.” British Journal of Cancer. 82(3): 718-25.

[22] Holmes, S.J. 1937. The Negro's Struggle for Survival: A Study in Human Ecology. Port Washington, NY: Kennikat Press, Inc.

[23] Margo, Robert and Richard H. Steckel. 1982. "The Heights of American Slaves: New Evidence on Slave Nutrition and Health.” Social Science History. 6: 516-38. 
[24] McKeown, Thomas. 1976. The Modern Rise of Population. London: Edward Arnold.

[25] McPherson, James M. 1965. The Negro's Civil War: How American Negroes Felt and Acted During the War for the Union. New York: Pantheon Books.

[26] Pope, Clayne. 1992. "Adult Mortality in America Before 1900: A View from Family Histories." In Claudia Goldin and Hugh Rockoff, Eds., Strategic Factors in Nineteenth Century American Economic History. Chicago: University of Chicago Press: 297-329.

[27] Preston, Samuel H. and Michael R. Haines. 1991. Fatal Years: Child Mortality in Late Nineteenth Century America. Princeton, NJ: Princeton University Press.

[28] Preston, Samuel H., Mark E. Hill, and Gregory L. Drevenstedt. 1998. "Childhood Conditions that Predict Survival to Advanced Ages Among African-Americans." Social Science and Medicine. 47(9): 231-46.

[29] Rose, Jerome C. 1989. "Biological Consequences of Segregation and Economic Deprivation: A Post-Slavery Population from Southwest Arkansas." Journal of Economic History. 49(2): 351-60.

[30] Steckel, Richard, H. 1986. "A Peculiar Population: The Nutrition, Health, and Mortality of American Slaves from Childhood to Maturity." Journal of Economic History. 46: 721-41.

[31] Smith, James P. 1986. "Race and Human Capital.” American Economic Review. 74(4): 68598.

[32] Troesken, Werner. 2004. Water, Race, and Disease. Cambridge, MA-London: MIT Press.

[33] Vickery, William Edward. 1977. The Economics of the Negro Migration, 1900-1960. New York: Arno Press.

[34] Woodbury, Robert Morse. 1926. Infant Mortality and Its Causes. Baltimore, MD: Williams and Wilkins. 
Table 1: Differential Ten Year Mortality Rates by Race and Cohort Among the Native-born Age $50-79$

\begin{tabular}{lrrrr}
\hline \hline \multicolumn{1}{c}{ Census Years: } & $1870-80$ & $1900-20$ & \multicolumn{2}{c}{$1940-2000$} \\
Birth Years: & $1791-1810$ & $1821-1860$ & $1861-1900$ & $1901-1940$ \\
\hline Linear specification & & & & \\
$\quad$ Coefficient on black & 0.001 & $0.123^{\ddagger}$ & $0.050^{\dagger}$ & 0.031 \\
$\quad$ Standard error & $(0.020)$ & $(0.013)$ & $(0.025)$ & $(0.023)$ \\
Adjusted $R^{2}$ & 0.938 & 0.962 & 0.851 & 0.777 \\
Log specification & & & & \\
Coefficient on black & 0.002 & $0.365^{\ddagger}$ & $0.164^{*}$ & $0.270^{*}$ \\
Standard error & $(0.062)$ & $(0.037)$ & $(0.093)$ & $(0.157)$ \\
Adjusted $R^{2}$ & 0.929 & 0.964 & 0.808 & 0.675 \\
Observations & 36 & 72 & 108 & 104 \\
Mean 10 year mortality rates & 0.317 & 0.360 & 0.334 & 0.212 \\
\hline \hline
\end{tabular}

Estimated from the Integrated Public Use Census Samples using Equations 1 and 2. Each observation is an age group, sex, cohort, region of birth (border, southern, and other), and race cell. The dependent variable is the 10 year mortality rate of each cell (or its logarithm). Additional controls include dummies for age 60-69 and age 70-79, female, region of birth, and birth cohort. The ordinary least squares regressions are weighted by cell size. The symbols $\ddagger$ and $*$ indicate that the coefficient is statistically significantly different from zero at the 1 and 10 percent level, respectively. 
Table 2: Differential Ten Year Mortality Rates at Ages 50-79 by Race and Cohort Among the Native Born 1821-1860 Cohorts

\begin{tabular}{|c|c|c|c|c|}
\hline & \multicolumn{2}{|c|}{ Linear Specification } & \multicolumn{2}{|c|}{ Logarithmic Specification } \\
\hline & $\begin{array}{l}\text { Coef- } \\
\text { icient }\end{array}$ & $\begin{array}{l}\text { Std. } \\
\text { Err. }\end{array}$ & $\begin{array}{l}\text { Coef- } \\
\text { icient }\end{array}$ & $\begin{array}{l}\text { Std. } \\
\text { Err. }\end{array}$ \\
\hline $\begin{array}{l}\text { Black } \\
\text { b. } 1821-1830\end{array}$ & 0.011 & 0.041 & 0.004 & 0.106 \\
\hline b.1831-1840 & 0.007 & 0.018 & 0.005 & 0.047 \\
\hline b. $1841-1850$ & 0.012 & 0.022 & 0.010 & 0.056 \\
\hline b. $1851-1860$ & 0.015 & 0.023 & 0.014 & 0.061 \\
\hline Black $\times$ b.1831-1840 & 0.059 & 0.046 & 0.146 & 0.120 \\
\hline Black $\times$ b.1841-1850 & $0.124^{\ddagger}$ & 0.043 & $0.398^{\ddagger}$ & 0.113 \\
\hline Black $\times$ b.1851-1860 & $0.154^{\ddagger}$ & 0.044 & $0.534^{\ddagger}$ & 0.116 \\
\hline Adjusted $R^{2}$ & 0.970 & & 0.969 & \\
\hline
\end{tabular}

Estimated from the Integrated Public Use Census Samples using Equations 1 and 2. Each observation is an age group, sex, cohort, region of birth (border, southern, and other), and race cell. 72 observations. The dependent variable is the 10 year mortality rate of each cell (or its logarithm). The weighted mean ten year mortality rate was 0.360 . Additional controls include dummies for age 60-69 and age 70-79, female, region of birth, and birth cohort. The ordinary least squares regressions are weighted by cell size. The symbols $\ddagger$ and $*$ indicate that the coefficient is statistically significantly different from zero at the 1 and 10 percent level, respectively. 
Table 3: Causes of Death by Race and Cohort

\begin{tabular}{lrrrrr}
\hline \hline & \multicolumn{2}{c}{ White } & \multicolumn{2}{c}{ Black } \\
& b.1821 & b.1831 & b.1841 & b.1831 & b.1841 \\
\hline Heart disease & 23.49 & 29.76 & 33.70 & 30.50 & 30.24 \\
Cerebrovascular disease & 6.76 & 10.99 & 13.14 & 7.80 & 7.80 \\
Bronchitis, pneumonia, and influenza & 10.32 & 9.75 & 8.89 & 13.48 & 14.63 \\
Infectious and parasitic & 11.03 & 6.38 & 4.28 & 4.96 & 4.88 \\
Genito-urinary & 7.30 & 11.25 & 12.36 & 12.06 & 15.12 \\
Chronic respiratory & 1.96 & 2.18 & 1.22 & 2.13 & 1.46 \\
Violence & 4.63 & 2.38 & 2.90 & 0.71 & 1.95 \\
Diabetes & 1.07 & 0.83 & 1.10 & 0.00 & 1.46 \\
Cancer & 3.56 & 4.56 & 6.16 & 2.13 & 2.44 \\
Stomach & 4.45 & 4.51 & 2.90 & 2.84 & 1.46 \\
Paralysis & 5.87 & 3.21 & 3.02 & 2.84 & 3.41 \\
Other & 19.57 & 14.20 & 10.32 & 20.57 & 15.12 \\
\hline \hline
\end{tabular}

The samples were restricted to men who were alive and on the pension rolls at age 60. No figures are given for the 1821 black cohort because the sample size is too small. 
Table 4: Effect of Race and Size of City of Enlistment and of 1900 Residence on Time Until Death From All Causes

\begin{tabular}{lrrr}
\hline \hline & \multicolumn{1}{c}{$\begin{array}{c}\text { Hazard } \\
\text { Ratio }\end{array}$} & $\begin{array}{c}\text { Hazard } \\
\text { Ratio }\end{array}$ & \multicolumn{1}{c}{$\begin{array}{c}\text { Hazard } \\
\text { Ratio }\end{array}$} \\
\hline Dummy=1 if black & $1.336^{\ddagger}$ & $1.282^{\ddagger}$ & $1.314^{\ddagger}$ \\
& $(0.064)$ & $(0.066)$ & $(0.069)$ \\
Dummy=1 if enlisted in large city & 1.083 & $1.085^{*}$ & $1.167^{\ddagger}$ \\
& $(0.084)$ & $(0.054)$ & $(0.065)$ \\
Black $\times$ enlisted in large city & & & $0.724^{\ddagger}$ \\
& & & $(0.088)$ \\
Dummy=1 if lived in one of & & & \\
100 largest cities in 1900 & $1.073^{*}$ & 1.030 & 1.020 \\
& $(0.041)$ & $(0.044)$ & $(0.044)$ \\
Black $\times 100$ largest city & & $1.231^{\dagger}$ & $1.276^{\ddagger}$ \\
$\gamma$ & & $(0.112)$ & $(0.118)$ \\
& $0.084^{\ddagger}$ & $0.084^{\ddagger}$ & $0.084^{\ddagger}$ \\
Log-Likelihood & $(0.001)$ & $(0.001)$ & $(0.001)$ \\
\hline \hline
\end{tabular}

All regressions are Gompertz hazard models. The sample consists of men who were age 50-74 and on the pension rolls in 1900. Additional control variables include dummies indicating occupation at enlistment (farmer, artisan, laborer, and professional or proprietor), dummies indicating occupation circa 1900 (farmer, artisan, laborer, and professional or proprietor), a dummy indicating whether the veteran could write, dummies indicating region of residence circa 1900 (east, midwest or west, border, and south), dummies indicating whether the soldier ever was a POW and whether the soldier ever had specific medical conditions while in service (tuberculosis, stomach, rheumatic fever, respiratory, diarrhea, typhoid, malaria, fever, and wound), age dummies, and dummies indicating missing occupation or size of city of residence or enlistment. The symbols $\ddagger$, $\uparrow$, and $*$ indicate that the coefficient is significantly different from 0 at the 1,5 , and 10 percent level respectively. 
Table 5: Effect of Race and Large City Residence in 1900 on Time Until Death From Specific Causes

\begin{tabular}{lrrr}
\hline \hline & $\begin{array}{c}\text { Infectious/ } \\
\text { Parasitic/ } \\
\text { Bronchitis } \\
\text { Hazard } \\
\text { Ratio }\end{array}$ & $\begin{array}{c}\text { Genito- } \\
\text { urinary } \\
\text { Hazard } \\
\text { Ratio }\end{array}$ & $\begin{array}{c}\text { Cerebro- } \\
\text { vascular } \\
\text { and Heart } \\
\text { Hazard } \\
\text { Ratio }\end{array}$ \\
\hline Dummy=1 if black & $\begin{array}{r}1.489^{\ddagger} \\
(0.0253)\end{array}$ & $\begin{array}{c}1.024 \\
(0.022)\end{array}$ & $\begin{array}{c}0.937 \\
(0.121)\end{array}$ \\
Dummy=1 if lived in one of & & & \\
100 largest cities in 1900 & 1.023 & 0.901 & 1.095 \\
& $(0.148)$ & $(0.140)$ & $(0.087)$ \\
Black $\times 100$ largest city & 1.307 & $1.967^{\dagger}$ & $1.528^{\dagger}$ \\
& $(0.366)$ & $(0.624)$ & $(0.294)$ \\
$\gamma$ & $0.063^{\ddagger}$ & $0.086^{\ddagger}$ & $0.096^{\ddagger}$ \\
Log-Likelihood & $(0.004)$ & $(0.005)$ & $(0.002)$ \\
\hline \hline
\end{tabular}

All regressions are Gompertz hazard models. The sample consists of who were age 50-74 and on the pension rolls in 1900. Additional control variables include dummies indicating occupation at enlistment (farmer, artisan, laborer, and professional or proprietor), dummies indicating occupation circa 1900 (farmer, artisan, laborer, and professional or proprietor), a dummy indicating whether the veteran could write, dummies indicating region of residence circa 1900 (east, midwest or west, border, and south), dummies indicating whether the soldier ever was a POW and whether the soldier ever had specific medical conditions while in service (tuberculosis, stomach, rheumatic fever, respiratory, diarrhea, typhoid, malaria, fever, and wound), age dummies, and dummies indicating missing occupation or size of city of residence or enlistment. The symbols $\ddagger, \dagger$, and $*$ indicate that the coefficient is significantly different from 0 at the 1,5 , and 10 percent level respectively. 
Table 6: Effect of Race and Cohort on Time Until Death From All Causes and from Specific Causes

\begin{tabular}{|c|c|c|c|c|}
\hline & $\begin{array}{c}\text { All } \\
\text { Causes } \\
\text { Hazard } \\
\text { Ratio }\end{array}$ & $\begin{array}{c}\text { Infectious/ } \\
\text { Parasitic/ } \\
\text { Bronchitis } \\
\text { Hazard } \\
\text { Ratio } \\
\end{array}$ & $\begin{array}{c}\text { Genito- } \\
\text { Urinary } \\
\text { Hazard } \\
\text { Ratio }\end{array}$ & $\begin{array}{c}\text { Cerebro- } \\
\text { vascular } \\
\text { and Heart } \\
\text { Hazard } \\
\text { Ratio }\end{array}$ \\
\hline Dummy $=1$ if black & $\begin{array}{c}1.111^{*} \\
(0.065)\end{array}$ & $\begin{array}{r}1.170 \\
(0.219)\end{array}$ & $\begin{array}{r}0.985 \\
(0.243)\end{array}$ & $\begin{array}{r}0.833 \\
(0.114)\end{array}$ \\
\hline $\begin{array}{l}\text { Dummy }=1 \text { if born before } 1841 \\
\text { Dummy=1 if born } 1841-52\end{array}$ & $\begin{array}{r}0.982 \\
(0.021)\end{array}$ & $\begin{array}{c}0.717^{\ddagger} \\
(0.054)\end{array}$ & $\begin{array}{r}1.083 \\
(0.093)\end{array}$ & $\begin{array}{c}1.110^{\dagger} \\
(0.049)\end{array}$ \\
\hline Black $\times$ b.1841-52 & $\begin{array}{r}1.384^{\ddagger} \\
(0.107)\end{array}$ & $\begin{array}{r}1.780^{\dagger} \\
(0.444)\end{array}$ & $\begin{array}{l}1.694^{*} \\
(0.524)\end{array}$ & $\begin{array}{r}1.290 \\
(0.231)\end{array}$ \\
\hline$\gamma$ & $\begin{array}{r}0.087^{\ddagger} \\
(0.001)\end{array}$ & $\begin{array}{r}0.067^{\ddagger} \\
(0.004)\end{array}$ & $\begin{array}{r}0.090^{\ddagger} \\
(0.005)\end{array}$ & $\begin{array}{r}0.093^{\ddagger} \\
(0.002)\end{array}$ \\
\hline Log-Likelihood & -10330.419 & -2496.661 & -1830.873 & -3854.649 \\
\hline
\end{tabular}

10,485 observations in the all cause mortality regression and 5,305 observations in the cause specific mortality regressions. The sample consists of men who were alive and on the pensions rolls at age 60. All regressions are Gompertz hazard models. Other causes of death are censored and assume independent competing risks. Additional control variables include a dummy equal to one if the soldier could write, dummies indicating occupation at enlistment, and dummmies indicating whether the soldier was ever a POW and whether the soldiers ever had specific medical conditions while in the service. The symbols $\ddagger, \uparrow$, and $*$ indicate that the coefficient is significantly different from 0 at the 1 , 5 , and 10 percent level respectively. 
Table 7: Effect of Cohort and Size of 1900 City of Residence on Time Until Death From All Causes and from Specific Causes for Black Veterans

\begin{tabular}{|c|c|c|c|c|}
\hline & $\begin{array}{c}\text { All } \\
\text { Causes } \\
\text { Hazard } \\
\text { Ratio }\end{array}$ & $\begin{array}{c}\text { Infectious/ } \\
\text { Parasitic/ } \\
\text { Bronchitis } \\
\text { Hazard } \\
\text { Ratio }\end{array}$ & $\begin{array}{l}\text { Genito- } \\
\text { Urinary } \\
\text { Hazard } \\
\text { Ratio }\end{array}$ & $\begin{array}{c}\text { Cerebro- } \\
\text { vascular } \\
\text { and Heart } \\
\text { Hazard } \\
\text { Ratio }\end{array}$ \\
\hline $\begin{array}{c}\text { Dummy }=1 \text { if lived in one of } \\
100 \text { largest cities in } 1900\end{array}$ & $\begin{array}{r}1.212 \\
(0.172)\end{array}$ & $\begin{array}{r}0.565 \\
(0.289)\end{array}$ & $\begin{array}{r}2.714^{\dagger} \\
(1.396)\end{array}$ & $\begin{array}{r}2.356^{\ddagger} \\
(0.694)\end{array}$ \\
\hline Dummy $=1$ if born before 1841 & & & & \\
\hline Dummy $=1$ if born $1841-52$ & $\begin{array}{r}1.295^{\ddagger} \\
(0.113)\end{array}$ & $\begin{array}{r}1.084 \\
(0.322)\end{array}$ & $\begin{array}{c}2.664^{\dagger} \\
(1.124)\end{array}$ & $\begin{array}{r}1.539^{*} \\
(0.362)\end{array}$ \\
\hline 100 largest city $\times$ b.1841-52 & $\begin{array}{r}1.085 \\
(0.198)\end{array}$ & $\begin{array}{r}2.532 \\
(1.540)\end{array}$ & $\begin{array}{r}0.633 \\
(0.410)\end{array}$ & $\begin{array}{r}0.665 \\
(0.258)\end{array}$ \\
\hline$\gamma$ & $\begin{array}{r}0.073^{\ddagger} \\
(0.005)\end{array}$ & $\begin{array}{r}0.063^{\ddagger} \\
(0.014)\end{array}$ & $\begin{array}{r}0.116^{\ddagger} \\
(0.017)\end{array}$ & $\begin{array}{r}0.084 \\
(0.010)\end{array}$ \\
\hline Log-Likelihood & -846.978 & -201.190 & -126.171 & -261.018 \\
\hline
\end{tabular}

766 observations in the all cause mortality regression and 363 observations in the cause specific mortality regressions. The sample consists of men who were alive and on the pensions rolls at age 60. All regressions are Gompertz hazard models. Other causes of death are censored and assume independent competing risks. Additional control variables include a dummy equal to one if the soldier could write, dummies indicating occupation at enlistment, and dummmies indicating whether the soldier was ever a POW and whether the soldiers ever had specific medical conditions while in the service. The symbols $\ddagger$, $\dagger$, and $*$ indicate that the coefficient is significantly different from 0 at the 1,5 , and 10 percent level respectively. 
Figure 1: Death Rates at Older Ages by Race, 1900-1998

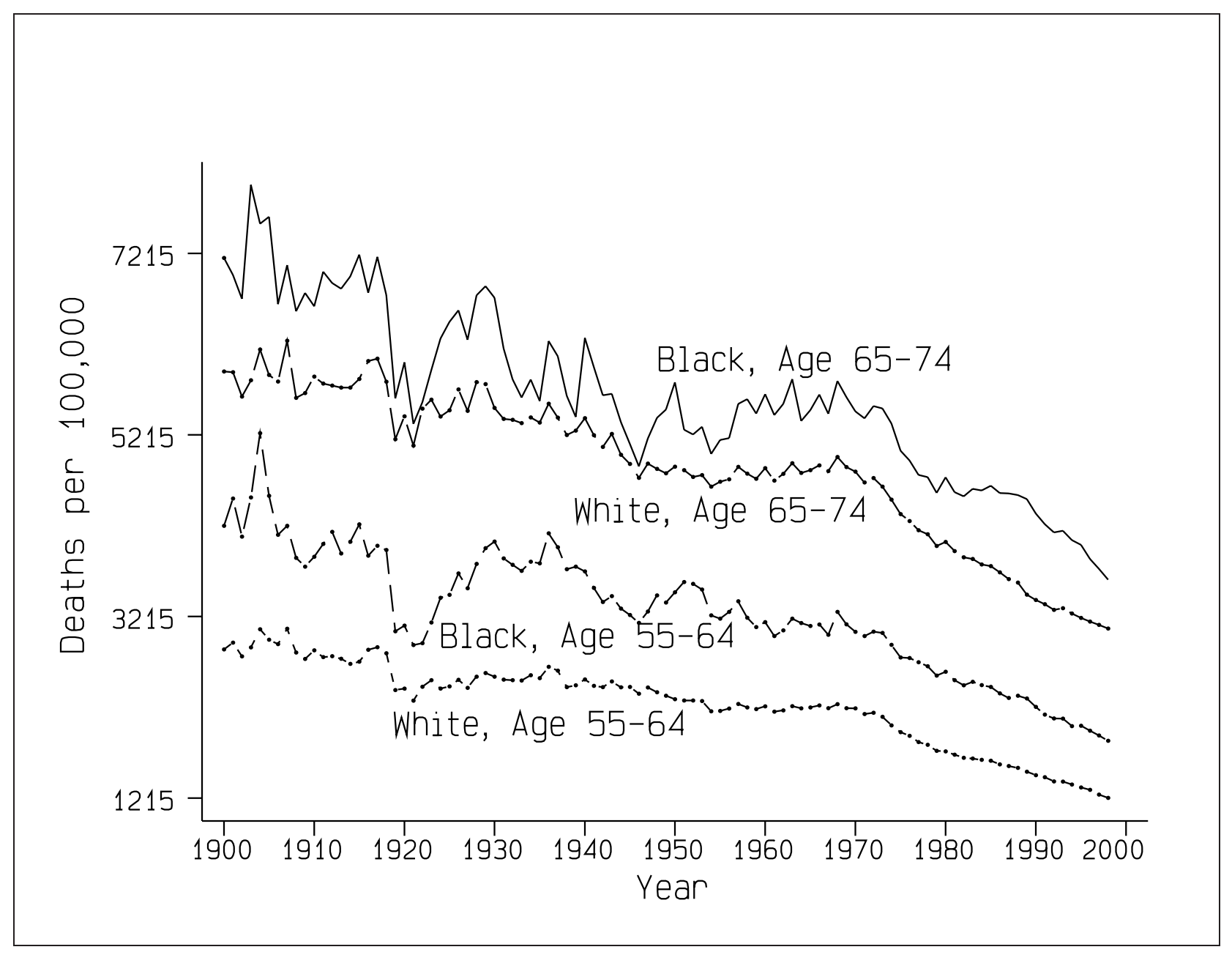

Source: Vital Statistics of the United States, various issues, and the Center for Disease Control's series hist290, http://www.cdc.gov/nchs/datawh/statab/unpubd/mortabs/hist290.htm. Deaths are for the death registration states only. 
Figure 2: Survival Probabilities by Race, Union Army Veterans and Men in NHANES I, Age 50-74

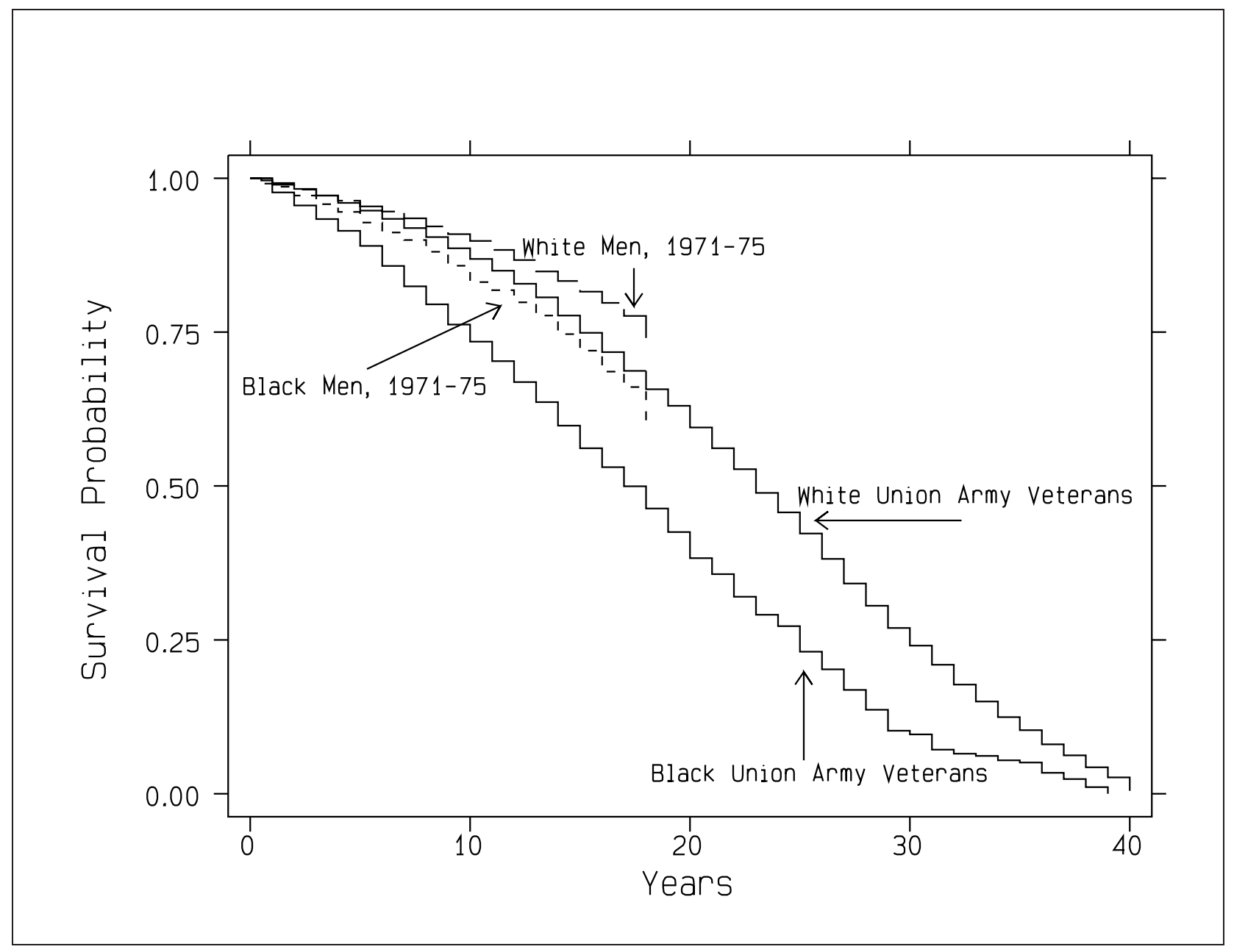

The Union Army sample is restricted to the native-born, those alive in 1900, and those on the pension rolls by 1900. All men are aged 50-74 at the time of observation. Survival curves are adjusted for age. 984 black Union Army veterans. 9,605 white Union Army veterans. 
Figure 3: Survival Probabilities by Race and Birthplace, Union Army Veterans

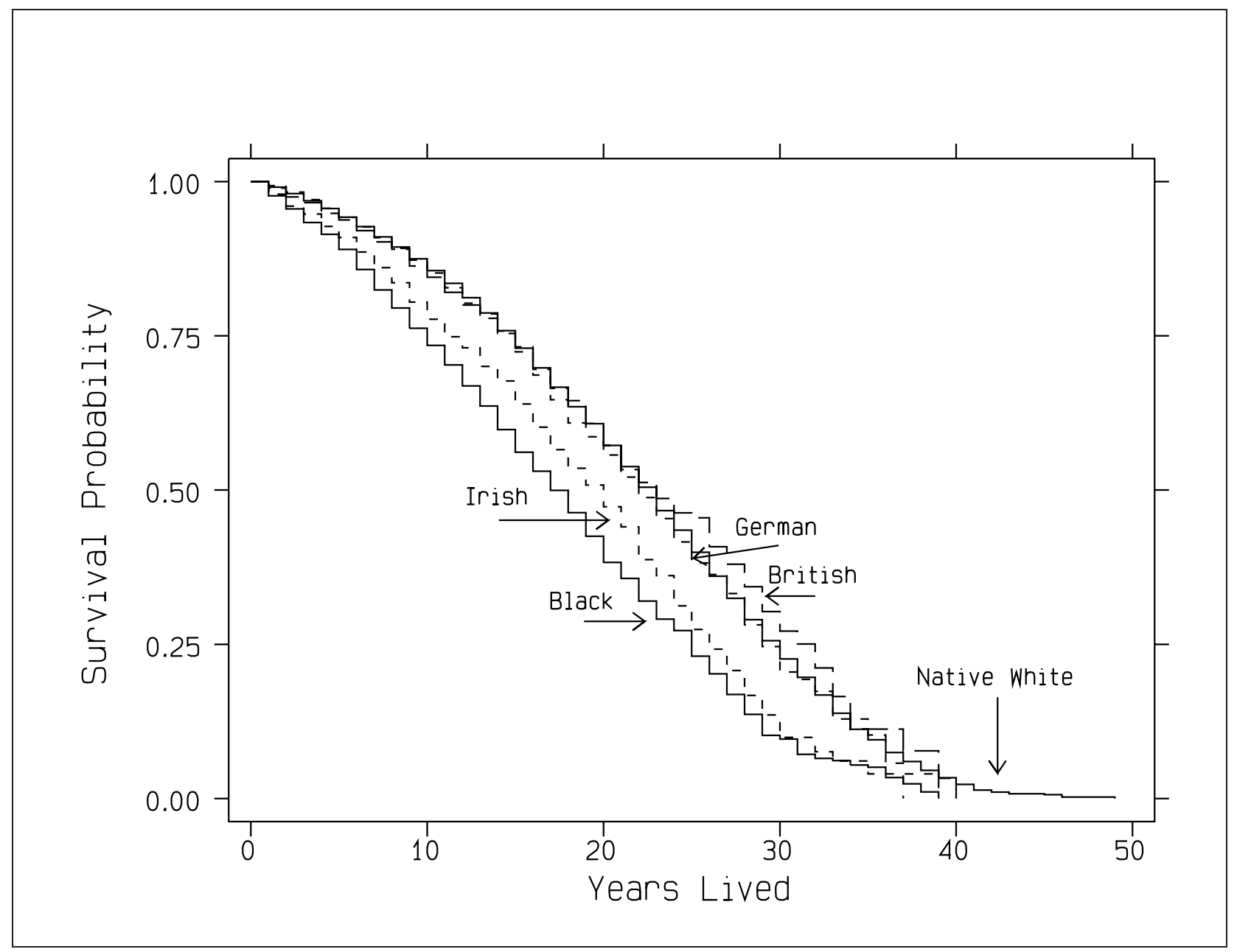

The Union Army sample is restricted to those alive in 1900 and to those on the pension rolls by 1900 . All men are aged 50-74 at the time of observation. Survival curves are adjusted for age. 894 blacks and 12,951 whites. 
Figure 4: Survival Probabilities by Race and Size City of Enlistment, Union Army Veterans

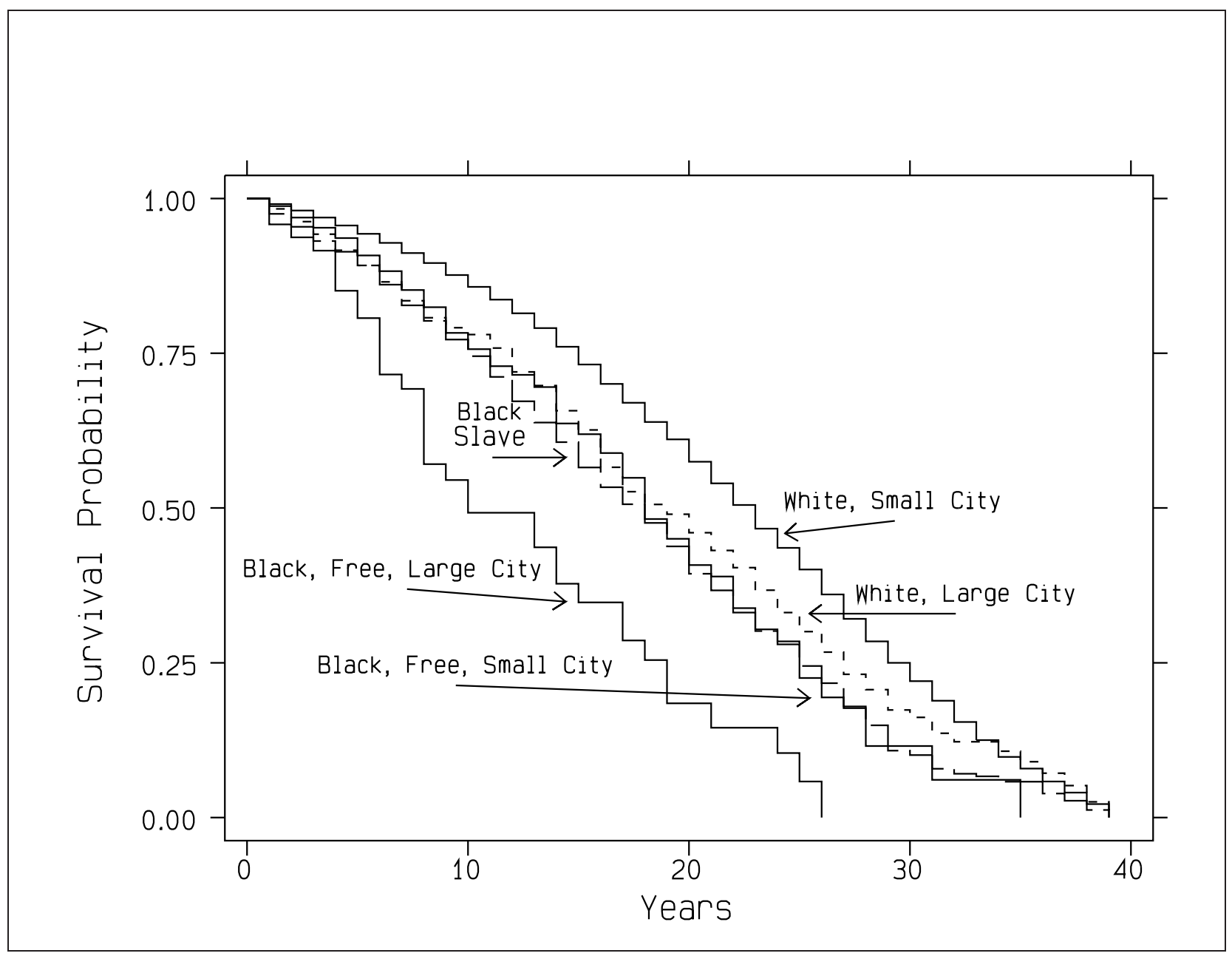

The Union Army sample is restricted to the native-born, to those alive in 1900, and to those on the pension rolls by 1900. All men are aged 50-74 at the time of observation. Survival curves are adjusted for age. City size is city at enlistment. A large city is defined as one with 50,000 or more people. 894 blacks and 9,605 whites. 
Figure 5: Survival Probabilities by Race and Size City of 1900 Residence, Union Army Veterans

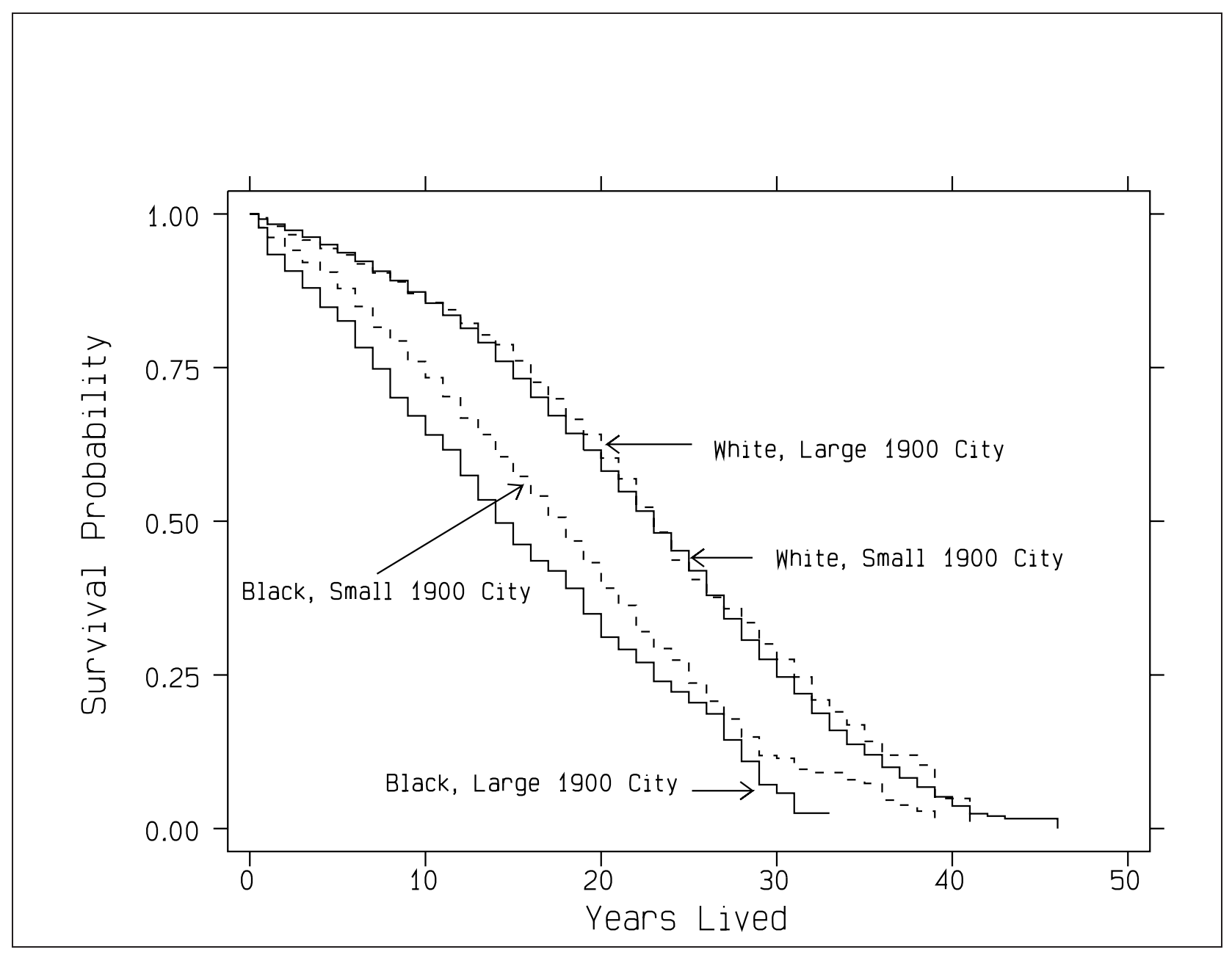

The Union Army sample is restricted to the native-born, to those alive in 1900, and to those on the pension rolls by 1900. All men are aged 50-74 at the time of observation. Survival curves are adjusted for age. A large city is one of the top 100 cities in 1900 and a small city is either a rural area or a city that was not one of the top 100 cities in 1900 . 894 blacks and 9,605 whites. 
Figure 6: Survival Probabilities by Race and Cohort, Union Army Veterans

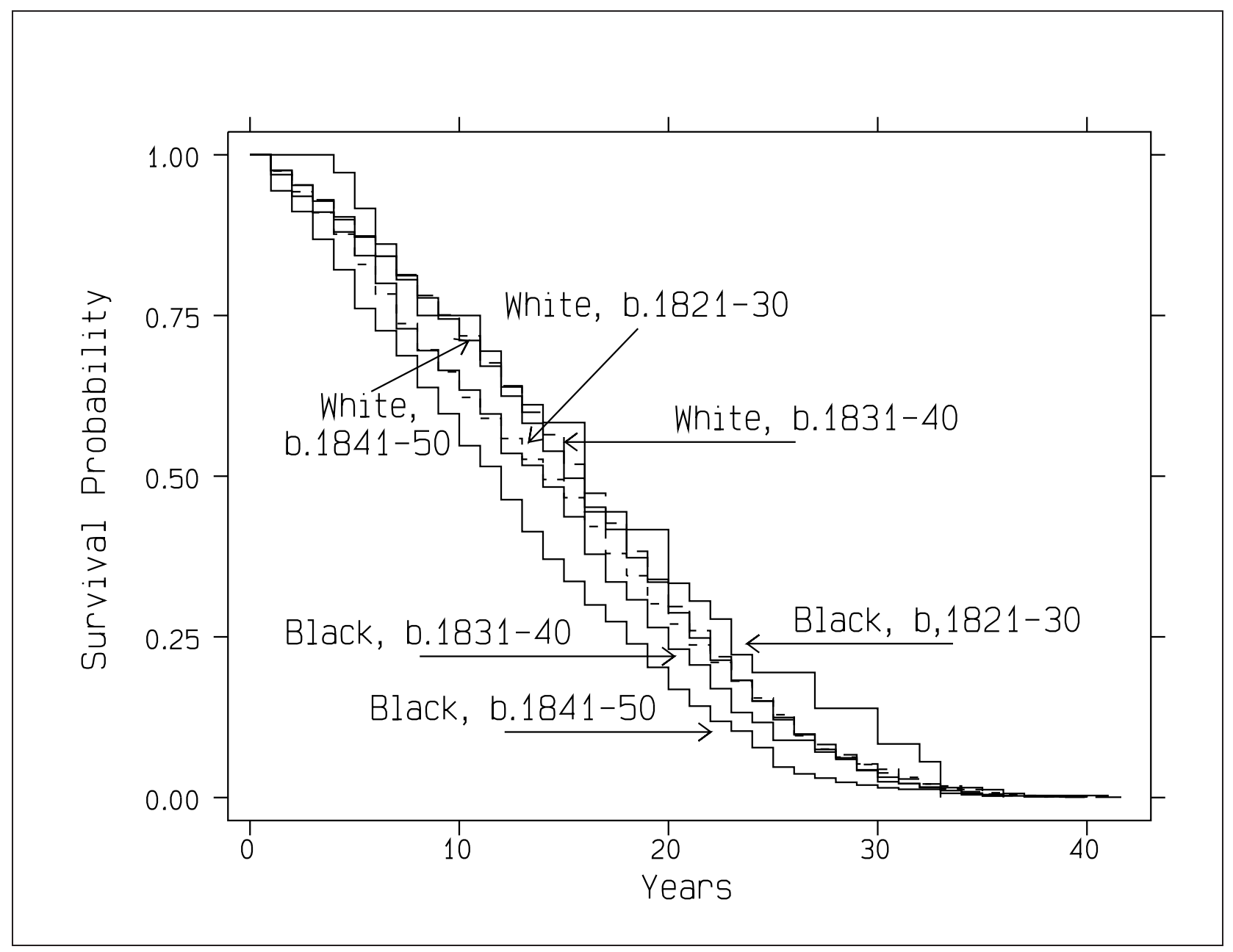

The Union Army sample is restricted to the native-born and those observed alive and on the pension rolls by age 60 . Years is years until death from age 60. 825 black Union Army veterans. 9,750 white Union Army veterans. 